\title{
The influence of habitat conditions on the plankton in the Białe oxbow lake (Nadbużański Landscape Park)
}

\author{
Agnieszka Pasztaleniec ${ }^{1}$, Maciej Karpowicz ${ }^{2}$, Małgorzata Strzałek ${ }^{3}$ \\ ${ }^{1}$ Department of Monitoring and Freshwater Assessment Methods, Institute of Environmental Protection - National Environmental \\ Institute, Kolektorska 4, 01-692 Warsaw, Poland; e-mail: paszta@ios.edu.pl (corresponding author) \\ ${ }^{2}$ Department of Hydrobiology, Institute of Biology, University of Bialystok, Świerkowa 20B, 15-950 Białystok, Poland \\ ${ }^{3}$ Department of Ecology and Environmental Protection, Siedlce University of Natural Sciences and Humanities, \\ Prusa 12, 08-110 Siedlce, Poland
}

\begin{abstract}
The spatial differentiation of the physico-chemical parameters $\left(\mathrm{Kd}_{\mathrm{PAR}}, \mathrm{pH}, \mathrm{DOC}\right.$, nutrient concentrations) and plankton communities (phytoplankton, Crustacea) was considered in the system: the water column without macrophytes, pleustophytes - lemnids (duckweeds) and hornwort Ceratophyllum demersum. It was demonstrated that at the study sites different habitat conditions occurred, which were related to the macrophyte assemblages. The highest values of the phytoplankton biomass and the greatest algal biodiversity were found in the site without vegetation, in both species-specific and functional terms. Zooplankton, dominated by Copepoda, reached the greatest density and species diversity at the Ceratophyllum site. Despite the substantial differentiation of habitats, the plankton diversity was quite low.
\end{abstract}

Key words: plankton, oxbow lakes, Ceratophyllum demersum

\section{Introduction}

The greatest advantage of the Nadbużański Landscape Park is the maintained Bug River valley, an area where the meandering river forms numerous oxbow lakes. The functioning of small water bodies depends on many environmental parameters, e.g. the concentrations of nutrients - phosphorus and nitrogen - mineral compounds, temperature, $\mathrm{pH}$ and water transparency. Given the small surface area and depth of these lakes and the related small volume, as well as the large differentiation of the morphometric conditions within the water body (depth, substrate type), the parameters listed above are characterised by large variations in time and space (Joniak 2009; Dembowska 2011). The variability of morphometric features and physico-chemical parameters affect the development of specific types of hydromacrophytes, the communities of which play in turn the habitat-making role, changing both the physical conditions (water transparency) and the chemical conditions (circulation of nutrients) and creating the substrate and refuges for aquatic organisms (Scheffer 2001). The substantial differentiation of higher vegetation communities within the reservoir can be seen distinctly in oxbow lakes, particularly those that remain unchanged by human activity (the absence of hydro-engineering and fishery facilities) and are located in river valleys with a natural hydrological cycle (Urban and Wójciak 2006; Strzałek and Koperski 2009). The enhancement of the speciesspecific differentiation of oxbow lakes is favoured by their usually elongated shape, the presence of numerous side bays, the accelerated succession manifested by the shallowing and progressive terrestrialisation of the branches, as well as - in the case of many meander lakes - large variations in the water table levels and/ or a periodical contact with river waters (Junk 1997).

In the national and foreign literature, data concerning oxbow lake plankton can be found; however, in most cases, the results of these analyses treat a water body as a whole, unifying the spatial differentiation to one designated point which is usually a fragment of the bottom uncovered by vegetation (Izaguirre et al. 2004; Jezierska-Madziar 2005; Wojciechowska et 
al. 2007), whereas the habitat-specific differentiation should be reflected in the formation of differentiated but also specific flora and fauna of plankton communities, as evidenced by the studies which have appeared in recent years, although there are still only a few (Kuczyńska-Kippen et al. 2009; Krasznai et al. 2010; Ligęza and Wilk-Woźniak 2011).

The aim of the research was to analyse the spatial differentiation of phytoplankton and crustacean zooplankton communities in terms of their density and diversity in relation to the different habitat conditions which ensue from the diversity of aquatic macrophyte composition in a small oxbow lake of the Bug River.

\section{Material and Methods}

The study was carried out in 2010 in an oxbow lake of the Bug River called Lake Białe, located in the Nadbużański Landscape Park (22 ${ }^{\circ} 19^{\prime} 11^{\prime \prime}$, $52^{\circ} 39^{\prime} 36^{\prime \prime} \mathrm{N}$ ), central and eastern Poland, Fig.1). Lake Białe is a small, shallow, eutrophic water body with a surface area of 1.1 ha and a maximum depth of 3.9 $\mathrm{m}$; without contact with river waters. The catchment of the reservoir is covered mainly by meadows and arable fields. The oxbow lake is strongly overgrown, covered to the extent of about $60 \%$ by vegetation dominated by Ceratophyllum demersum L., with Stratiotes aloides $\mathrm{L}$. as the accompanying species in the littoral zone. From the early spring a substantial part of the lake (about 30\%) was covered by a thick layer of pleustophytes with the dominant species Spirodela polyrhiza (L.) Schleiden, Lemna trisulca L. and Lemna minor L. Samples were taken at three sites representing different microhabitats of the lake (Fig. 1). Site 1 was characterised by water fully covered by free-floating vegetation (Lemnaceae); Site 2 was situated in the central, deepest part of the lake $(3.5 \mathrm{~m})$ and constituted an open water column without vegetation; and Site 3 was overgrown by a meadow of hornwort (C. demersum) with a small number of lemnids in the summer (Table 1). The test samples for each of the sites were taken three times - in the spring (June), the summer (August) and the autumn (October).

The basic physico-chemical parameters (water temperature, $\mathrm{pH}$, oxygenation, DOC, electrolytic conductivity) and the concentration of chlorophyll $a$ were measured directly in the field using a multiparameter sonde (YSI 650 MDS). Water samples for chemical and phytoplankton analyses were taken using a 2-litre Ruttner sampler from $0.5 \mathrm{~m}$ depth. Photosynthetically active light (PAR 400-700 nm) was measured using a light meter from Li-Cor Biosciences, using at the same time light sensors for underwater and surface measurements (Underwater Quantum Sensor Li192 SA, Quantum Sensor Li 190SA, LI-COR Biosciences, Lincoln, IL, USA). Measurements of light transmittance in the water column were recorded every $25 \mathrm{~cm}$. On

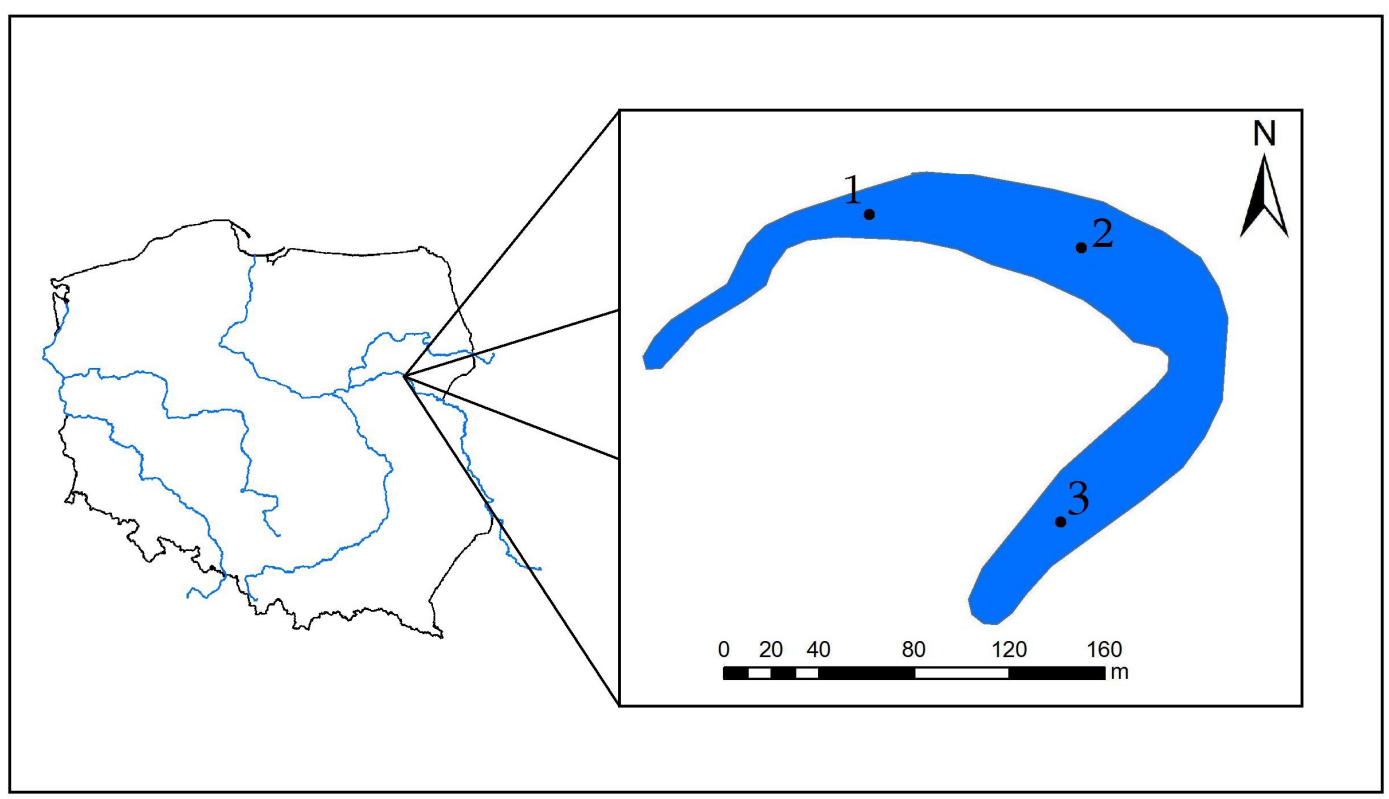

Fig. 1. Location of sampling sites in the oxbow Lake Białe 
their basis, the light absorption coefficient was calculated as a logarithmicised value of the penetrating radiation in relation to depth.

Chemical analyses (TP, TN, N-NH, $\mathrm{N}_{4} \mathrm{NO}_{3}$, $\left.\mathrm{P}-\mathrm{PO}_{4}\right)$ were carried out by the standard methods (APHA 1999). Samples for quantitative phytoplankton analyses were fixed directly after their collection using Lugol's solution and then preserved with a $4 \%$ formaldehyde solution at a laboratory. The number of algal cells was calculated using an inverted microscope, according to Utermöhl's method (Vollenweider 1969). Depending on the sample density, sedimentation chambers with volumes of 5,50 or $100 \mathrm{ml}$ were used, identifying at least 100 specimens in a sample. The biomass was estimated on the basis of the number and measured volumes of cells, according to the method proposed by Hillebrand et al. 1999. In order to perform quantitative phytoplankton analyses, samples were collected using a plankton net with a $25 \mu \mathrm{m}$ mesh diameter. The determinations were carried out on living material and on that fixed with Lugol's solution using an optical microscope Nikon Eclipse E200. Because of the small depth of the investigated lake, samples also contained typical periphyton species or ones belonging to phytobenthos, which were taken into account in the total number. The determined species were assigned to the functional groups (FG) sensu Reynolds et al. 2002 and Padisák et al. 2009, as well as to the morpho-functional groups (MFG) sensu Salmaso and Padisák 2007.

The samples for crustacean zooplankton analyses were collected using a 2-litre Ruttner sampler from $0.5 \mathrm{~m}$ depth. The samples were densified by pouring a known volume of water through a plankton net with a $25 \mu \mathrm{m}$ mesh diameter and then preserved with a $4 \%$ formaldehyde solution. After sedimentation the samples were densified to about $25 \mathrm{ml}$ and the fixed material was determined in taxonomic terms using an optical microscope Nikon Eclipse E200. The speciesspecific, functional and morpho-functional diversities were determined with the Shannon-Weaver and evenness coefficients using the MVSP programme (Kov. Comp. Serv. 1985-2009) on the basis of the number (zooplankton) and biomass (phytoplankton).

\section{Results and Discussion}

Table 1 shows the physico-chemical parameters which characterised the investigated sites of Lake Białe. Most of them indicated the differentiation among the investigated sites. The highest temperature, water transparency, $\mathrm{pH}$, the degree of water oxygenation and concentrations of the total fractions of phosphorus and nitrogen were identified at Site 2 without higher vegetation. Site 1 , shaded in the spring and the summer with patches of duckweeds, demonstrated the highest values of the parameters listed above, but the lowest concentrations of ammonium nitrogen. At Site 3 , the environmental variables reached intermediate values. No differentiation was found among the investigated sites in the case of alkalinity and electrolytic conductivity. The coefficients of variation $(\mathrm{CV})$ of the basic physico-chemical parameters at the research sites of Lake Białe, in the particular seasons of the year, indicate the greatest differentiation of the investigated parameters at the research sites in the summer (Fig. 2). It was in this period that the fullest development of aquatic vegetation, capable of significantly affecting the formation of specific habitats, could be seen (Gasith and Hoyer 1998). The dense layer of duckweed practically prevented the penetration of sunlight in the water column $\left(\mathrm{Kd}_{\mathrm{PAR}}=14.48 \mathrm{~m}^{-1}\right)$ at Site 1, impeding the growth of algae (the total phytoplankton biomass was barely $0.2 \mathrm{mg} \mathrm{dm}^{-3}$, with the concentration of chlorophyll $a$ equal to $12.0 \mu \mathrm{g} \mathrm{dm}^{-3}$ ), and causing thereby a drop in oxygenation and a lowering of the water reaction. Similarly, a low density of phytoplankton (the concentrations of the total biomass and chlorophyll $a$ were, respectively, $0.2 \mathrm{mg} \mathrm{dm}^{-3}$ and 10.4 $\mu \mathrm{g} \mathrm{dm}^{-3}$ ) was recorded at the site with Ceratophyllum demersum (Site 3). This fact can be explained by the simultaneous rapid growth of the copepod population, primarily the larval forms of Cyclopoida (mainly nauplii), which are macrofiltrators feeding primarily on plankton algae (Fig. 3). The number of Cyclopoida at this site amounted to 142.6 ind. $\mathrm{dm}^{-3}$ and was higher by a multiple factor than those at the other sites in this period; however, adult specimens represented less than $10 \%$ of the total number of copepods. In the hornwort patch the density of Cladocera could also be seen to grow; however, their number (11 ind. $\mathrm{dm}^{-3}$ ) was slight compared with copepods (Fig. 4). Thus, the meadows of Ceratophyllum demersum constituted good refuges for crustacean zooplankton. The effect consisting in a substantial growth of the number of copepods in a water column at a site with a bottom overgrown by $C$. demersum in a small pond in western Poland was also found by Kuczyńska-Kippen and Nagengast 2006. A partly adverse impact on the phytoplankton community could also be exerted by the 
Table 1. Limnological parameters (mean, minimum and maximum values) of the oxbow Lake Białe at sampling sites

\begin{tabular}{|c|c|c|c|c|}
\hline \multicolumn{2}{|c|}{ Variable } & Station 1 & Station 2 & Station 3 \\
\hline \multicolumn{2}{|c|}{ Depth at sampling site [m] } & 2.5 & 3.5 & 2.2 \\
\hline \multicolumn{2}{|c|}{ Temperature $\left[{ }^{\circ} \mathrm{C}\right]$} & $13.5(5.5-18.3)$ & $14.6(5.6-20.5)$ & $13.5(5.6-18.8)$ \\
\hline \multicolumn{2}{|c|}{$\mathrm{Kd}_{\mathrm{PAR}}\left[\mathrm{m}^{-1}\right]$} & $10.73(5.30-14.48)$ & $4.47(3.26-5.36)$ & $6.46(4.14-9.73)$ \\
\hline \multicolumn{2}{|l|}{$\mathrm{pH}$} & $7.3(7.2-7.4)$ & $7.8(7.7-8.0)$ & $7.7(7.5-7.9)$ \\
\hline \multicolumn{2}{|c|}{ Conductivity $\left[\mu \mathrm{S} \mathrm{cm}^{-1}\right]$} & $397(370-424)$ & $414(388-433)$ & $412(384-431)$ \\
\hline \multicolumn{2}{|c|}{ Alkalinity [mval dm-3] } & $4.8(4.2-5.2)$ & $4.8(4.2-5.2)$ & $4.8(4.2-5.2)$ \\
\hline \multicolumn{2}{|c|}{ Dissolved oxygen [mg dm${ }^{-3}$ ] } & $6.1(4.0-8.3)$ & $8.5(1.2-12.3)$ & $6.0(2.0-12.0)$ \\
\hline \multicolumn{2}{|c|}{$\mathrm{TP}\left[\mathrm{mg} \mathrm{dm}^{-3}\right]$} & $0.23(0.15-0.28)$ & $0.32(0.19-0.53)$ & $0.28(0.19-0.35)$ \\
\hline \multicolumn{2}{|c|}{$\mathrm{TN}\left[\mathrm{mg} \mathrm{dm}^{-3}\right]$} & $1.88(1.72-2.19)$ & $2.58(1.77-3.00)$ & $2.38(2.00-2.80)$ \\
\hline \multicolumn{2}{|c|}{ Orthophosphate $\left[\mathrm{mg} \mathrm{dm}^{-3}\right]$} & $0.09(0.01-0.20)$ & $0.06(0.001-0.14)$ & $0.07(0.003-0.13)$ \\
\hline \multicolumn{2}{|c|}{ Nitrate $\left[\mathrm{mg} \mathrm{dm}^{-3}\right]$} & $0.13(0.06-0.22)$ & $0.14(0.04-0.24)$ & $0.16(0.09-0.28)$ \\
\hline \multicolumn{2}{|c|}{ Ammonium [mg dm$\left.{ }^{-3}\right]$} & $0.25(0.05-0.59)$ & $0.21(0.01-0.52)$ & $0.24(0.02-0.56)$ \\
\hline \multicolumn{2}{|c|}{ Chl-a $\left[\mu \mathrm{g} \mathrm{dm}^{-3}\right]$} & $14.3(12.0-15.3)$ & $23.2(13.8-28.1)$ & $19.4(10.4-32.2)$ \\
\hline \multirow{8}{*}{ 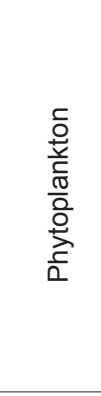 } & Biomass [mg dm ${ }^{-3}$ ] & $2.5(0.2-3.4)$ & $12.5(1.2-26.7)$ & $4.5(0.4-9.9)$ \\
\hline & Species number & $11(8-23)$ & $12(8-15)$ & $13(9-16)$ \\
\hline & Species diversity & $1.08(0.85-2.42)$ & $1.96(0.92-2.79)$ & $1.67(0.73-2.42)$ \\
\hline & Species evenness & $0.49(0.32-0.61)$ & $0.54(0.31-0.72)$ & $0.44(0.23-0.61)$ \\
\hline & Functional diversity & $1.43(0.80-2.07)$ & $1.75(0.92-2.25)$ & $1.29(0.73-2.02)$ \\
\hline & Functional evenness & $0.42(0.20-0.58)$ & $0.54(0.31-0.62)$ & $0.40(0.24-0.59)$ \\
\hline & MFG diversity & $1.68(0.71-2.29)$ & $1.74(0.89-2.50)$ & $1.48(0.71-2.15)$ \\
\hline & MFG evenness & $0.51(0.29-0.62)$ & $0.55(0.32-0.58)$ & $0.49(0.25-0.65)$ \\
\hline \multirow{4}{*}{ 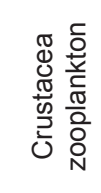 } & Total number [ind. $\mathrm{dm}^{-3}$ ] & $16.43(2.30-40.00)$ & $19.00(0.40-39.00)$ & $61.07(4.22-168.00)$ \\
\hline & Species number & $6(5-7)$ & $2(2-3)$ & $7(6-9)$ \\
\hline & Species diversity & $1.72(1.04-2.42)$ & $0.89(0.78-1.00)$ & $1.65(1.36-2.02)$ \\
\hline & Species evenness & $0.70(0.40-0.86)$ & $0.74(0.49-1.00)$ & $0.58(0.50-0.72)$ \\
\hline \multicolumn{2}{|c|}{$\begin{array}{l}\text { Character of vegetation } \\
\text { Dominating macrophytes }\end{array}$} & $\begin{array}{c}\text { Pleustophytes } \\
\text { Lemna spp., Spirodela polyrhiza }\end{array}$ & Open water without plants & $\begin{array}{l}\text { Submerged macrophytes } \\
\text { Ceratophyllum demersum }\end{array}$ \\
\hline
\end{tabular}

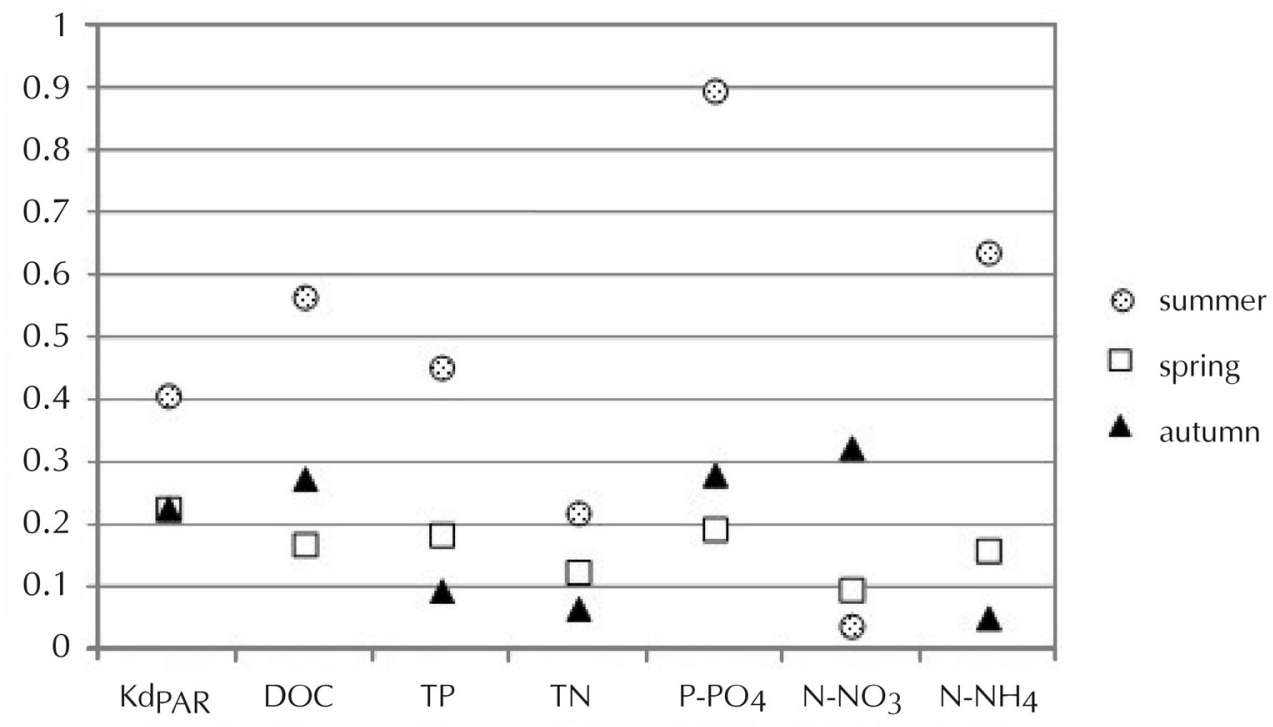

Fig. 2. Coefficient of variation $(\mathrm{CV})$ of basic physico-chemical water parameters at sampling sites during the vegetation period 


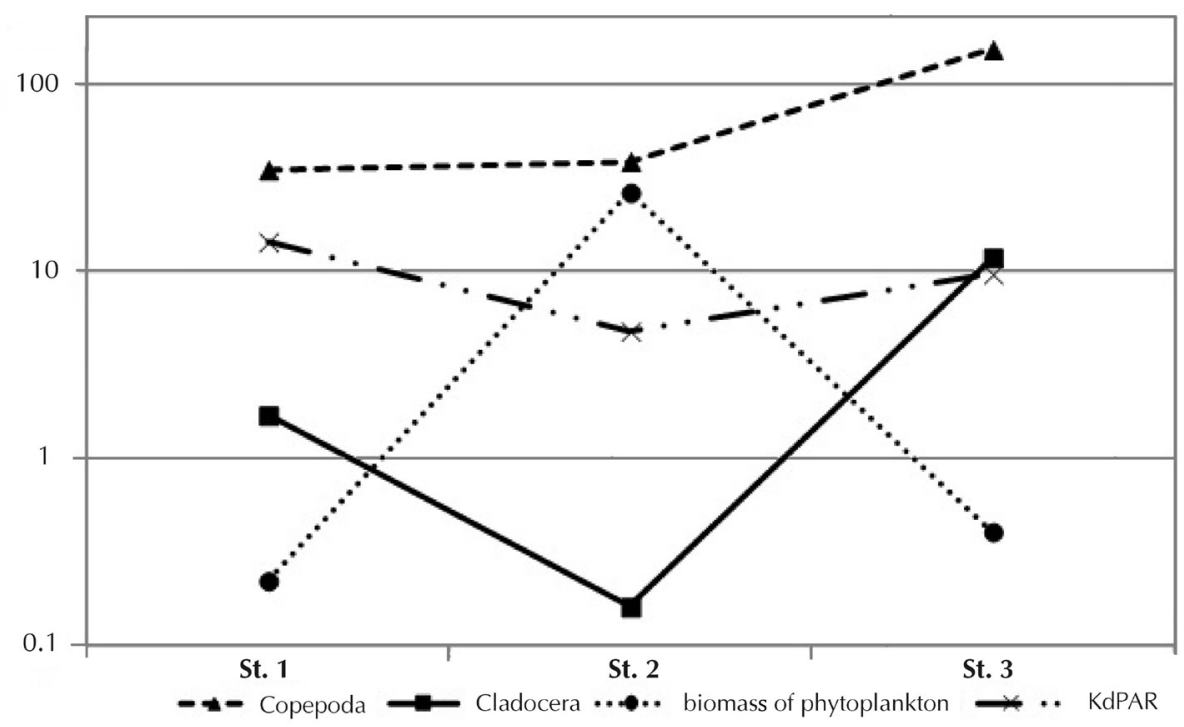

Fig. 3. Crustacean zooplankton density, phytoplankton biomass with changes in water illumination conditions $\left(\mathrm{Kd}_{\mathrm{PAR}}\right)$ in summer at sampling sites (on logarithmic scale)

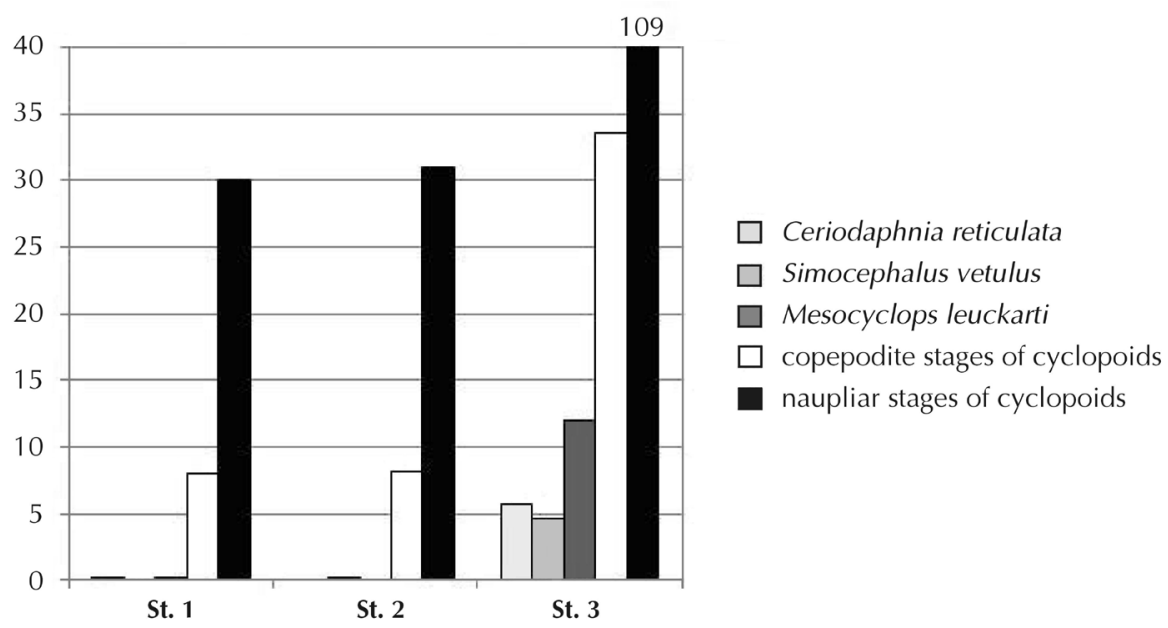

Fig. 4. Density (ind. $\mathrm{dm}^{-3}$ ) of dominant taxa of crustacean zooplankton at sampling sites of the oxbow Lake Białe (summer period)

occurring species of duckweeds. Although they were relatively rare, their concentrations lowered the light transmittance and the absorption coefficient was 9.7 $\mathrm{m}^{-1}$. The highest light transmittance, the absence of macrophytes and the simultaneous access to nutrients caused the most intense growth of biomass in Lake Białe at the middle site (Table 1). In the summer, the phytoplankton density reached its maximum values and the total biomass was $26.7 \mathrm{mg} \mathrm{dm}^{-3}$ with the chlorophyll $a$ concentration being $28.1 \mu \mathrm{g} \mathrm{dm}^{-3}$.

In the oxbow lake a total of 53 phytoplankton species were identified. Blue-green algae, euglenids,
Chrysophyta, Cryptophyta, Dinophyta, diatoms and Chlorophyta had the largest shares in the biomass; in addition, phytoplankton communities which were significantly different in terms of their qualitative structure were found in the summer (Fig. 5). At Site 1 diatom species of periphyton and benthal origin dominated (about 70\%) of the genera Navicula, Epithemia and Achnathes. Their share at Site 3 was about $20 \%$, while they were absent at the middle site. The presence of diatom specimens in phytoplankton samples resulted from the small depth and the occurrence of vegetation, which provided the substrate for their 

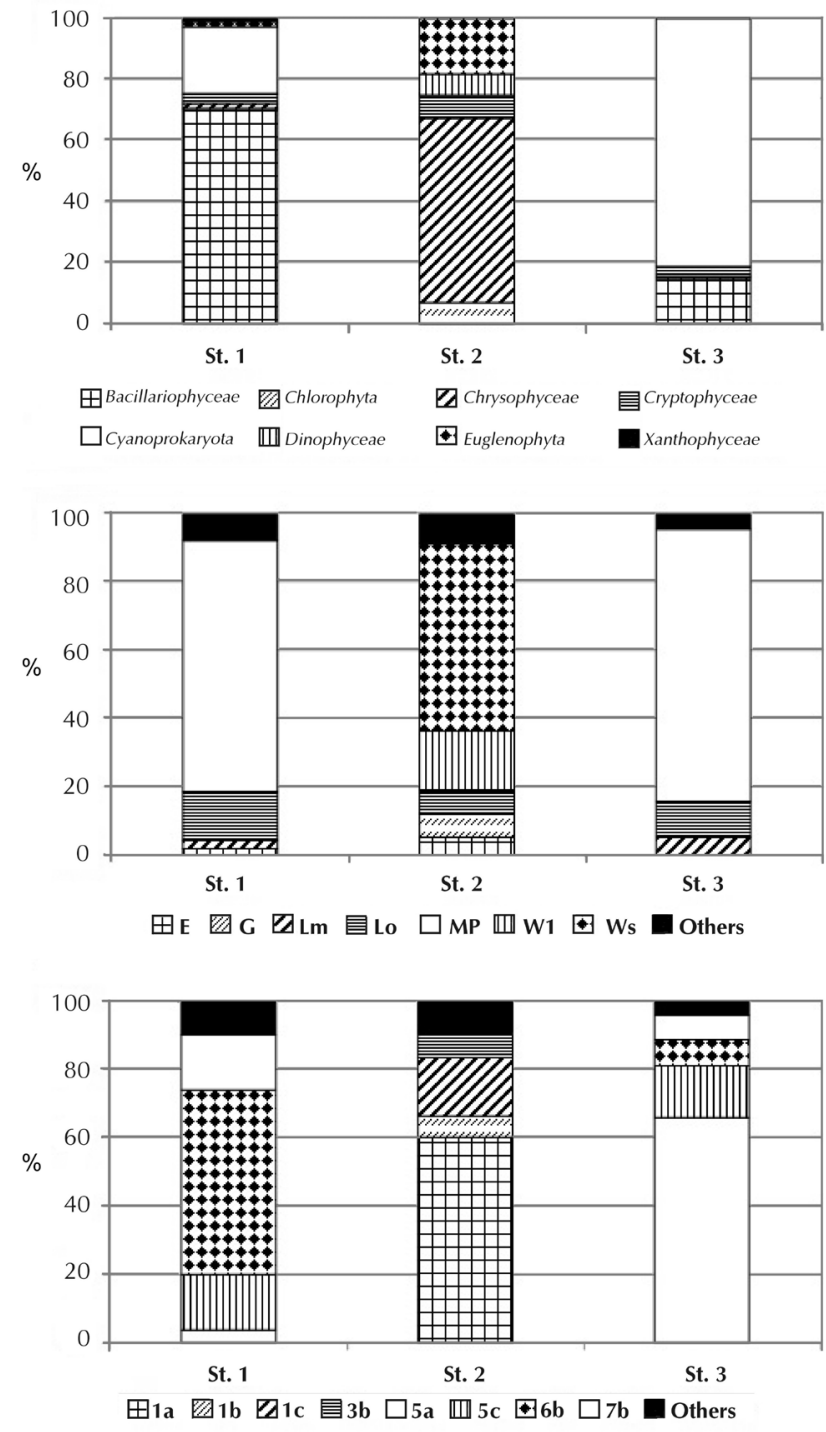

Fig. 5. Percentage share of taxonomic (A), functional (B) and morpho-functional groups (C) in the total biomass of summer phytoplankton at sampling sites of oxbow Lake Białe

development. Although they are not typical plankton organisms, in the classification sensu Reynolds et al. 2002, they were separated to form a different functional group (MP) characteristic of shallow river lakes (Padisák et al. 2009; Krasznai et al. 2010). The MP group also consists of Cyanoprokaryota species; in the case of the investigated lake these included Oscillatoria limosa C.Agardh, O. subcapitata Ponomarev and $O$. simplicissima (Gomont). Given the distinct domination of the MP codon, in functional terms, the phytoplankton community was to a large extent homogeneous at both shallow sites where macrophytes dominated. In both cases, the accompanying group was the
Lo group, including the blue-green alga Merismopedia tenuissima Lemmermann (Fig. 5). There had been reports on the allelopathic impact of $C$. demersum on phytoplankton in experimental conditions, primarily in respect of blue-green algae. At Site 3 overgrown by this species in Lake Białe this dependence was not observed. Similarly, the domination of blue-green algae at sites with $C$. demersum in the shallow Lake Jarosławieckie was demonstrated by Pełechata and Pełechaty 2010. In these cases, it can indicate the key role of morphometry and zooplankton in the shaping of the qualitative composition of algae. The water column at Site 2 was inhabited by Chrysophyta with the dominant Synura uvella Ehrenberg (the Ws codon) and euglenids (the $\mathbf{W} \mathbf{1}$ codon). Given the mixotrophic properties of the listed groups of algae, enabling them to feed on organic matter, in which oxbow lakes are rich, but also the presence of flagella and the related ability to move to the best lighted water layers, the species of Euglenophyta and Chrysophyceae often occur in large abundance in lakes of this type (Izaguirre et al. 2004; Wojciechowska et al. 2007; Pełechata and Pełechaty 2010; Ligęza and Wilk-Woźniak 2011). The greatest dissimilarity of the assemblages of plankton alga at the investigated sites could be seen in the morpho-functional approach sensu Salmaso and Padisák 2007. More than half the phytoplankton biomass consisted of groups of large Pennate diatoms - $\mathbf{6 b}$ (Site 1); large Chrysophyta colonies - 1a (Site 2) and filamentous blue-green algae - 5a (Site 3).

The species-related richness of the phytoplankton of Lake Białe was relatively low, as the presence of several to a dozen or so species on average was found (Table 1). As regards biodiversity, irrespective of whether the diversity and evenness of phytoplankton communities were considered in species-related, functional or morpho-functional terms, the highest values of the Shannon-Weaver and evenness coefficients were calculated for the data from Site 2 (Table 1, Fig. 5). The lack of competition on the part of macrophytes and the more diversified environmental conditions enabled the coexistence of algal species with different life strategies. Conversely, in the case of crustacean zooplankton, the greatest species-related differentiation and density were found at Site 3 dominated by submerged vegetation (Figs. 3 and 4). A larger number of zooplankton species at sites with patches of aquatic plants compared with open waters was also demonstrated by other authors (Kuczyńska-Kippen and Nagengast 2006; Strzałek and Koperski 2009). In 
Lake Białe there were relatively few littoral-specific species of Crustacea (Simocephalus vetulus and $\mathrm{Ce}$ riodaphnia reticulata), which often dominate in the zooplankton structure in small water reservoirs. Their largest share occurred at Site 3. In general, the crustacean zooplankton in the investigated water body was characterised by small species-specific differentiation expressed by the Shannon-Weaver coefficient biodiversity index and the small number of the occurring species (Table 1). In turn, the relatively high number of Crustacea was caused by the domination of the larval forms of Cyclopoida in the summer. The zooplankton structure indicated a relatively high trophy of the investigated lake, also given such features as the distinct domination of copepods over cladocerans in the structure of crustacean zooplankton and the low value of the average size of a single specimen.

A review of the literature indicates that oxbow lakes are usually exceptionally rich in terms of the number and diversity of species (Gasith and Hoyer 1998; Jezierska-Madziar 2005; Wojciechowska et al. 2007; Krasznai et al. 2010). Despite the large number of microhabitats in the investigated lake, the poor species-specific diversity of phyto- and zooplankton may be caused by the lack of contact between the oxbow lake and the waters of the Bug River, even during spring floods. According to Junk's theory the "flood pulse" is a decisive factor affecting the occurrence of species, the productivity of the lake-river system and the increase in biodiversity in the lakes in river valleys, and also modifying interactions between environmental formations (Junk 1997).

However, on the basis of the research performed, it can be said that, despite the small size of the investigated lake, within it there are habitats with specific plankton flora and fauna. Their differentiation involves different types of aquatic plants inhabiting them, thus confirming the thesis posed by Gasith and Hoyer 1998, according to which in shallow and small reservoirs macrophytes may have a potentially significant impact on the physico-chemical properties of water, the internal supply of nutrients and biotic interactions. The cited authors also emphasise that relatively small and isolated plant patches may be distinctly more important than has been assumed to date. Both approaches to phytoplankton analysis which were applied in the study, i.e. the one based on the response of organisms to environmental variables (FG) and the divisions assumed a priori in morphological terms (MFG), reflect the spatial differentiation of the qualitative structure of algae and can be applied in comparative analyses.

\section{Conclusions}

In the studied oxbow lake, most of the physicochemical parameters (temperature, water transparency, $\mathrm{pH}$, water oxygenation, $\mathrm{TP}, \mathrm{TN}$ ) indicated the differentiation between the investigated sites related to the type of macrophyte assemblages (lack of macrophytes, pleustophytes or domination of elodeides). The different habitat conditions entailed the differentiation of plankton communities (phytoplankton, Crustacea). The highest values of the phytoplankton biomass and the greatest algal biodiversity of species, functional and morpho-functional groups were found in the site without vegetation. Zooplankton, dominated by Copepoda, reached the greatest density and species diversity at the site overgrown by submergd macrophytes while cyanobacteria reached the highest percentage share in the total phytoplankton biomass. Under the pleustophytes cover, periphiton and benthal diatoms dominated and the number of crustacean zooplankton was low.

\section{References}

[APHA] American Public Health Association, 1999, Standard methods for the examination of water and waste water, Am. Publ. Health Assoc., New York, p. 1220.

Dembowska E., 2011, Cyanobacterial blooms in shallow lakes of the Iławskie Lake District, Limnol. Rev. 11, 2: 69-79.

Gasith A., Hoyer M. V., 1998, Structuring role of macrophytes in lakes: Changing influence along lake size and depth gradients, [in:] Jeppesen E., Søndergaard Ma., Søndergaard Mo., Christofferson K. (eds), The structuring role of submerged macrophytes in lakes, SpringerVerlang, New York: 381-392.

Hillebrand H., Dürselen C.-D., Kirschtel D., Pollingher U., Zahary T., 1999, Biovolume calculation for pelagic and benthic microalgae, J. Phycol. 35: 403-424.

Izaguirre I., O’Farrell I., Unrein F., Sinistro R., dos Santos Afonso M., Tell G., 2004, Algal assemblages across a wetland, from a shallow lake to relictual oxbow lakes (Lower Paraná River, South America), Hydrobiologia 511: 25-36.

Jasser I., 1995, The influence of Ceratophyllum demersum on phytoplankton community in experimental conditions, Hydrobiologia 306: 21-32.

Jezierska-Madziar M., 2005, Starorzecza jako istotny element ekosystemu rzecznego (Oxbow lakes as a significant element of a river ecosystem), Wyd. ARPoz., Poznań, p. 167 (in Polish). 
Joniak T., 2009, Charakterystyka hydrochemiczna wód i zarys chemizmu osadów dennych drobnych zbiorników wodnych krajobrazu rolniczego i leśnego (Hydrochemical characteristics of waters and an outline of the chemism of sediments of small water bodies in the pastoral and forest landscape), [in:] Kuczyńska-Kippen N. (ed.), Functioning of plankton communities in habitat differentiated small water bodies of the Wielkopolska area, Wyd. Bonami, Poznań: 33-59 (in Polish).

Junk W.J., 1997, The Central Amazon Floodplain: Ecology of a Pulsing System, Springer-Verlag, New York, p. 525.

Krasznai E., Borics G., Várbíró G., Abonyi A., Padisák J., Deák C., Tóthmérész B., 2010, Characteristics of the pelagic phytoplankton in shallow oxbows, Hydrobiologia 639: 173-184.

Kuczyńska-Kippen N., Nagengast B., 2006, Impact of a sudden water level decrease on the biocoenotic structure of a small pastoral water body, Teka Kom. Ochr. Kszt. Przyr. 3: 104-114.

Kuczyńska-Kippen N., Nagengast B., Celewicz-Gołdyn S., Klimko M., 2009, Zooplankton community structure within various macrophyte stands of a small water body in relation to seasonal changes in water level, Oceanol. Hydrobiol. Stud. 38(3): 125-133.

Ligęza S., Wilk-Woźniak E., 2011, The occurrence of a Euglena pascheri and Lepocinclis ovum bloom in an oxbow lake in southern Poland under extreme environmental conditions, Ecol. Indicat. 11: 925-929.
Padisák J., Crossetti L.O., Naselli-Flores L., 2009, Use and misuse in the application of the phytoplankton functional classification: a critical review with updates, Hydrobiologia 621: 1-19.

Pełechata A., Pełechaty M., 2010, The in situ influence of Ceratophyllum demersum on a phytoplankton assemblage, Oceanol. Hydrobiol. Stud. 39(1): 95-101.

Reynolds C.S., Huszar V., Kruk C., Naselli-Flores L., Melo S., 2002 , Towards a functional classification of the freshwater phytoplankton, J. Plankton Res. 24: 417-428.

Salmaso N., Padisák J., 2007, Morpho-Functional Groups and phytoplankton development in two deep lakes (Lake Garda, Italy and Lake Stechlin, Germany), Hydrobiologia 578: 97-112.

Scheffer M., 2001, Ecology of Shallow Lakes, Kluwer Academic Publishers, Dortrecht-Boston-London, p. 357.

Strzałek M., Koperski P., 2009, The Stratiotes aloides L. stand as a habitat in oxbow lake Bużysko, Aquat. Bot. 90: 1-6.

Urban D., Wójciak H., 2006, Aquatic plant communities of the Lemnatea minoris R. Tx. 1955 class in the Bug valley old river-beds against the habitat conditions, Teka Kom. Ochr. Kszt. Środ. Przyr. 3: 241-249.

Wojciechowska W., Pasztaleniec A., Solis M., 2007, Diversity and dynamics of phytoplankton in floodplain lakes (Bug River, eastern Poland), Oceanol. Hydrobiol. Stud. 36: 199-208.

Vollenweider R.A. (ed.), 1969, A manual on methods for measuring primary production in aquatic environments, Blackwell, Oxford-Edinburgh, p. 45. 